\title{
RESEARCH PAPER \\ Technical efficiency for a sample of Chilean wine grape producers: A stochastic production frontier analysis
}

\author{
Víctor H. Moreira ${ }^{1}$, Javier L. Troncoso ${ }^{2}$, and Boris E. Bravo-Ureta ${ }^{3}$ \\ ${ }^{1}$ Instituto de Economía Agraria, Universidad Austral de Chile, PO Box 567, Valdivia, Chile. \\ ${ }^{2}$ Departamento de Economía Agraria, Universidad de Talca, PO Box 747, Talca, Chile. \\ ${ }^{3}$ Agricultural and Resource Economics, University of Connecticut, Storrs, CT 06269-1182, USA, and \\ Adjunct Professor, Departamento de Economía Agraria, Universidad de Talca.
}

\begin{abstract}
V.H. Moreira, J.L. Troncoso, and B.E. Bravo-Ureta. 2011. Technical efficiency for a sample of Chilean wine grape producers: A stochastic production frontier analysis. Cien. Inv. Agr. 38(3):321-329. Chile has become an increasingly important player in international wine markets. Concurrent with the expansion of Chilean wine output and exports, there has been an increase in production in several other "New World" countries including Argentina, Australia, New Zealand and South Africa. The overall growth in wine supplies has increased competition to capture market share, which highlights the importance of productivity gains among wine and grape producers. The purpose of this paper is to estimate and analyze the technical efficiency (TE) component of productivity for a sample of wine grape producers in Chile. The data includes 38 farms with specific input-output information for individual blocks yielding a total of 263 observations. We use a Cobb-Douglas model to estimate a stochastic production frontier (SPF) and to obtain TE scores both at the individual block and at the farm level. The results suggest that the average farm level TE is $77.2 \%$, while the block level TE ranges from 23.4 to $95.0 \%$. The value of the function coefficient is 1.021 , which suggests nearly constant returns to size.
\end{abstract}

Key words: Chile, stochastic production frontiers, technical efficiency, wine grapes.

\section{Introduction}

The increase in wine production in New World wine countries has been a recent success that has caused traditional wine exporting countries like France, Spain and Italy (Anderson, 2005) to lose market share. In particular, Chile has become an increasingly important player in international wine markets, but the overall expansion

Received August 16, 2010. Accepted June 21, 2011. Corresponding author: vmoreira@uach.cl in wine supplies has led to growing competition to capture market share, and this highlights the significance of productivity gains for both wine and grape producers. Productivity concerns are even more pressing during economic recessions when the demand for many products, including wine, tends to soften.

The remarkable expansion of the Chilean wine industry over the past two decades has been fuelled primarily by the opportunities offered by the growth in international markets. While in 1990, 
most of the wine produced in Chile was consumed domestically, and exports accounted for only $7 \%$ of the total production, in 2009, approximately $64 \%$ of Chilean wines were exported. During the same time period, vineyard plantations almost doubled, going from 65,000 to 117,600 hectares, and wine production, initially 2.6 million hectolitres, quadrupled to 10.0 million hectolitres. By the same token, the value of exports grew from US \$80 million in 1990 to US \$1,280 million in 2009 (Foster and Valdés, 2001; ODEPA, 2010a). Wine is now one of the most important single export commodities in Chilean trade, contributing nearly $12 \%$ of the value of all forestry and agricultural exports combined (ODEPA, 2010b).

The strategy followed by the Chilean wine industry to date has been to capture markets based on 'good quality at a low price.' For 2006, red wines rated as "very good" and "outstanding" by the specialized magazine Wine Spectator, retail market prices were reported in the U.S. at $20 \%$ and $32 \%$ lower than the prices commanded by Californian and French wines of equivalent ratings. Similarly, in the United Kingdom, the same Chilean wines were under priced by $54 \%$ and $53 \%$ compared to their Italian and French equivalents. This under pricing is reflected in the low and almost stagnant FOB price in Chile, which grew at a modest 2.2 cents per dollar per liter annually (Escobar, 2007) during the period 1995-2005.

The export orientation of the Chilean wine industry makes income heavily dependent on FOB prices and the exchange rate, two variables that are beyond any control of the producers. Hence, costs, yields, managerial performance and productivity growth are essential for the commercial success of this industry. To be profitable, firms have to seek minimum costs within the technological bounds required to produce the high-quality product demanded by international markets. Efficiency must be an important consideration throughout the production chain, starting at the vineyard, passing through the winery and ending in the marketing process.
A study by CORFO (2004) established that grapes account for more than $30 \%$ of the cost of a liter of wine in the Chilean industry; this is one of the most significant variables in the cost structure of wine making. Any efficiency gains at the vineyard level can have an important impact on the commercial success of the whole operation.

The wine industry in Chile is composed of two primary groups of firms: big corporations and family-owned estates. Although both groups are oriented to the export market, the former tends to sell a more massive product, while many of the firms in the latter group, known as boutique vineyards, are focused on the elaboration of exclusive and sophisticated wines that are produced on a reduced scale. A group of 44 boutique vineyards formed a consortium in 2006, known as 'Tecnovid,' primarily to finance viticultural and oenological research projects of common interest to the vineyards (Tecnovid, 2010). In 2006, Tecnovid represented only $7 \%$ of all wines exported but obtained an average price of US \$2.26 per liter, which compared favorably to the US $\$ 1.89$ per liter received on average for the wines from the 10 largest corporations (Tecnovid, 2006).

This study concentrates on vineyards affiliated with Tecnovid, i.e., vineyards that produce grapes that are expected to result in high-quality wines when processed in their wine cellars.

Although many studies have been published around the world examining the technical efficiency (TE) component of productivity in farming (Bravo-Ureta et al., 2007), there appears to be only a handful of such studies focusing on productivity and TE in wine grape production. One such study is by Townsend et al. (1998) who analyzed the relationship between farm size, productivity and returns to scale for wine grape producers located in four regions of South Africa for the years 1992 to 1995. Another study for South Africa, by Conradie et al. (2006), examined the relationship between TE and farm size for samples of Western Cape Province producers. These authors estimated 
stochastic production frontier (SPF) models using panel data for wine grape farms located in the Robertson and Worcester regions for the years 2003 and 2004, and cross-sectional data for table grape farms located in the De Doorns region for 2004. A more recent study was conducted by Henriques et al. (2009) who used non-parametric techniques to measure TE for a sample of 22 wine grape farms from the Alentejo region of Portugal for the years 2001 and 2004 .

The purpose of this paper is to analyze the TE component of productivity for a sample of wine grape producers in Chile using a SPF approach and cross-sectional data.

\section{Materials and methods}

\section{Stochastic Production Frontier (SPF)}

To achieve the proposed objectives, SPFs are estimated using a sample of Chilean wine grape producers. Frontier models can be classified into two basic types: parametric or non-parametric. Parametric frontiers require the specification of a particular functional form and can be classified as deterministic or stochastic. The deterministic model assumes that any deviation from the frontier is due to inefficiency, while stochastic frontiers incorporate statistical noise. In deterministic frontier models, any measurement error and any other source of stochastic variation in the dependent variable is attributed to inefficiency, making the estimations of TE sensitive to extreme values (Greene, 1993). The SPF resolves the problem of extreme values by incorporating a compound error with a two-sided symmetrical term and a onesided component. The latter reflects inefficiency, while the two-sided error captures the random effects outside the control of the production unit.

The production frontier used here follows the structure established by Battese and Coelli (1992), which has become very popular in recent years. In 1995, these authors published an extension of the original model, which is typically used when data is available that can be used to explain the variation in TE (Battese and Coelli, 1995). However, in the present study, such data were not available.

In accordance with Battese and Coelli (1992), the SPF can be represented as:

$Y_{i t}=\exp \left(x_{i t} \beta+v_{i t}-u_{i t}\right)$

where $Y_{i t}$ is the output of the $\mathrm{i}$-th farm in the t-th time period; $x_{i t}$ is a vector $(1 x K)$ of inputs and other explanatory variables for the $\mathrm{i}$-th farm in the t-th time period; $\beta$ is a vector $(K \times 1)$ of the unknown parameters to be estimated; $v_{i t}$ is the random error, which should have a normal distribution with mean zero and constant variance $\left(\sigma_{v}^{2}\right)$, that is $v_{i} \sim \operatorname{iid} N\left(0, \sigma_{v}^{2}\right)$; and $u_{i t}$ is the non-observable and non-negative random error that captures the technical inefficiency for the i-th farm.

Once the SPF model is estimated, TE for the i-th farm is given by:

$\mathrm{TE}=\exp \left(-u_{i}\right)$,

where $u_{i}$ is specified in equation [1]. The TE for each farm is calculated by using the conditional expectation of $-u_{i}$, given the composed error term (v-u) (Jondrow et al., 1982). All these calculations were performed using the software FRONTIER 4.1, which provides maximum likelihood estimates for the parameters of the stochastic frontier model (Coelli, 1996).

An important parameter in the SPF model, usually referred to as $\gamma$, is the ratio between the variance of the one-sided error $\left(\sigma_{u}^{2}\right)$ and the total variance $\left(\sigma_{v}^{2}+\sigma_{u}^{2}\right)$; that is, $\gamma=\sigma_{u}^{2} /\left(\sigma_{v}^{2}+\right.$ $\left.\sigma_{u}^{2}\right)$ and consequently ranges between 0 and 1 (Battese and Corra, 1977). The null hypothesis that technical inefficiency is not present in the model, i.e., $\gamma=0$, is readily testable. This test in essence contrasts the stochastic frontier model with the average production function. 
Data and Empirical Model: Descriptive statistics for the data used in this analysis are presented in Table 1. The data was obtained from a sample of 38 Chilean wine grape producers that belong to Tecnovid. At the time the survey was conducted, Tecnovid included a total of 44 firms, and all of them were invited to provide data for a benchmarking study. The data used in this paper correspond to the 38 grape producers that accepted the invitation to participate in the initial study. These producers export more than $90 \%$ of their wine production and, as indicated earlier, are classified as boutique wine producers. The data was collected by researchers from the Universidad de Talca in Central Chile and corresponds to the agricultural year 2005-2006.

Each producer in the sample manages several blocks. A block represents a particular variety with specific management. The number of blocks per farm goes from a low of two to a high of 17 with an average of seven. Therefore, the total number of observations is 263 , which is the total number of blocks for the 38 farms. The grapes are classified according to quality as Premium and Varietal, and the number of blocks is equally distributed between each category. Most of the grapes are produced in a simple cordon training system (73\%), followed by a double cordon training system (13\%). All the farms are located in Central Chile but scattered from north to south in the following 10 valleys: Limarí, Aconcagua, Casablanca, San Antonio, Maipo, Cachapoal, Rapel, Colchagua, Curicó and Maule, as depicted in Table 1.

The SPF is estimated using the Cobb-Douglas functional form. This model can be represented as:

$Y_{i}=\alpha_{0}+\sum_{k=1}^{4} \beta_{k} X_{k i}+\beta_{A} A G_{i}+\beta_{W} W N_{i}+$

$\beta_{Q} Q L_{i}+\sum_{l=1}^{4} \beta_{l} F R_{l}+\sum_{m=1}^{7} \beta_{m} V L_{m}+v_{i}-u_{i}$

where the sub-index $k$ represents the k-th explanatory variable, and $i$ reflects a specific block in a given farm. The dependent variable $(Y)$ is the natural loga- rithm of the annual output per block for each farm, measured in kilograms. The explanatory variables, also expressed in natural logarithms, are the following: $X_{1}$ is the block size measured in hectares; $X_{2}$ is the total cost of labor measured in Ch\$ per block; $X_{3}$ is the total cost of machinery measured in Ch\$ per block; and $X_{4}$ is the total cost of fertilizer and pesticides measured in $\mathrm{Ch} \$$ per block.

The SPF also includes the following control variables: $A G$ is a binary variable equal to 1 if a block is five years or older and 0 otherwise; $W N$ is a binary variable equal to 1 for red wine grapes and 0 otherwise; $Q L$ is a proxy for grape quality and is equal to 1 for premium and 0 for varietal; $F R_{l}$ is a set of dummy variables that captures the type of training system, including "simple" and "double" cordon, "pergola" and "other training" systems, which is the excluded category. $V L_{m}$ is another set of dummy variables that account for unobserved heterogeneity associated with the valley(s) in which the farm is located. Initial regressions indicated that the following clustering of valleys was a reasonable specification for these dummy variables: Aconcagua and Cachapoal, Colchagua and Rapel, Casablanca, Curicó, Maipo, Maule, and Limarí and San Antonio, the excluded category. The random terms $v_{i}$ and $u_{i}$ are already defined in equation [1], and the Greek letters represent the parameters to be estimated.

\section{Results and discussion}

\section{SPF estimates}

Table 2 presents the estimated model and a test of the statistical significance of the $\gamma$ parameter $\left(\mathrm{H}_{0}: \gamma=0\right)$. The $\gamma$ parameter is equal to 0.942 and is highly significant ( $1 \%$ level), which indicates that the model is indeed a stochastic frontier. The stochastic frontier dominates the average production function.

As also shown in Table 2, the most influential variables, according to the partial elasticity of production, are land or block size (0.62), labor 
Table 1. Descriptive statistics of wine grape farms.

\begin{tabular}{|c|c|c|c|c|}
\hline Variable & Unit & Average & Min. & Max. \\
\hline Number of farms & number & 38 & & \\
\hline Size of farms & ha & 86.8 & 4.0 & 414.0 \\
\hline Number of blocks per farm & number & 7 & 2 & 17 \\
\hline Size of blocks & ha & 12.5 & 0.2 & 108.7 \\
\hline Grape production & $\mathrm{Kg} / \mathrm{ha}$ & 10,445 & 1,372 & 27,132 \\
\hline Labor cost & $\mathrm{US} \$ 1 / \mathrm{ha}$ & 849 & 315 & 1,516 \\
\hline Machinery cost & US\$1/ha & 346 & 65 & 809 \\
\hline Inputs (e.g., fertilizer, pesticides) & US\$1/ha & 339 & 38 & 1,214 \\
\hline Age of plantation & years & 16 & 3 & 118 \\
\hline \multicolumn{5}{|l|}{ Type of wine: } \\
\hline - Red & $\%$ & 71 & & \\
\hline - White & $\%$ & 29 & & \\
\hline \multicolumn{5}{|l|}{ Grape quality: } \\
\hline - Premium & $\%$ & 50 & & \\
\hline - Varietal & $\%$ & 50 & & \\
\hline \multicolumn{5}{|l|}{ Training system: } \\
\hline - Simple cordon & $\%$ & 73 & & \\
\hline - Double cordon & $\%$ & 13 & & \\
\hline - Pergola & $\%$ & 7 & & \\
\hline - Others & $\%$ & 7 & & \\
\hline \multicolumn{5}{|c|}{ Location (Geographical Valley, from north to south of Chile): } \\
\hline - Limarí & $\%$ & 4 & & \\
\hline - Aconcagua & $\%$ & 6 & & \\
\hline - Casablanca & $\%$ & 8 & & \\
\hline - San Antonio & $\%$ & 2 & & \\
\hline - Maipo & $\%$ & 15 & & \\
\hline - Cachapoal & $\%$ & 11 & & \\
\hline - Rapel & $\%$ & 2 & & \\
\hline - Colchagua & $\%$ & 30 & & \\
\hline - Curicó & $\%$ & 6 & & \\
\hline - Maule & $\%$ & 16 & & \\
\hline
\end{tabular}

${ }^{1}$ The exchange rate used is the average for $2005 / 2006$ and US\$1 $=\mathrm{Ch} \$ 542$ (Central Bank of Chile, www.bcentral.cl).

$(0.29)$ and machinery $(0.10)$. The partial elasticity of production for other inputs (fertilizer and pesticides) is 0.02 , but it is not statistically significant. The sum of these elasticities is 1.021 , which reveals the presence of nearly constant returns to size.

Blocks that are five years of age or older exhibit a higher level of production, as expected. In addition, red wine grape varieties have lower production levels than those for white wines, as do the grapes destined for the production of premium wines compared to varietal grapes. The latter result is expected because premium quality implies a more selective harvest, which means a more severe pruning during dormancy and fruit thinning during the growing season. The pergola training system produces more grapes than other systems, although statistically this is a nonsignificant difference, while both the simple and double cordon training systems are significantly 
Table 2. Parameter estimates for a Cobb-Douglas Stochastic production frontier for Chilean vineyards.

\begin{tabular}{lccc}
\hline Variable & Coefficient & Significance & Standard Error \\
\hline Constant & 4.160 & $* * *$ & 1.070 \\
Labor cost & 0.285 & $*$ & 0.072 \\
Machinery cost & 0.099 & & 0.053 \\
Other inputs & 0.021 & $* * *$ & 0.030 \\
Block size & 0.617 & & 0.084 \\
Control variables & & $* * *$ & \\
Age of plantation $(>5)$ & 0.334 & $* * *$ & 0.091 \\
Red wine & -0.174 & $* * *$ & 0.042 \\
Premium & -0.179 & $* * *$ & 0.040 \\
Single cordon & -0.217 & & 0.078 \\
Double cordon & -0.198 & $* * *$ & 0.098 \\
Pergola & 0.027 & & 0.100 \\
Aconcagua and Cachapoal & 0.220 & $* .090$ \\
Casablanca & -0.153 & $* * *$ & 0.107 \\
Maipo & -0.109 & $* * *$ & 0.090 \\
Colchagua and Rapel & 0.311 & $* *$ & 0.084 \\
Curicó & 0.409 & & 0.110 \\
Maule & 0.305 & & 0.087 \\
Function Coefficient & 1.021 & $* * *$ & 0.205 \\
Value, Log Likelihood Function & -63.598 & 0.619 & \\
$\sigma^{2}$ & 0.942 & & 0.028 \\
$\gamma$ & $610 c k$ & & \\
\hline
\end{tabular}

The dependent variable is grape output per block in $\mathrm{kg}$.

$* * * 1 \%$ of the level of significance.

$* * 5 \%$ of the level of significance.

$* 10 \%$ of the level of significance.

less productive compared to the omitted category. The farm location can influence grape production significantly, as revealed by the parameters of the corresponding dummy variables, although no discernable pattern is exhibited from north (Limarí) to south (Maule). Casablanca and Maipo exhibit lower production even after controlling for the premium wine grapes that are common in these locations. As indicated earlier, the valley dummies are incorporated to capture unobserved heterogeneity associated with geographical location and agro-ecological aptitudes.

\section{Technical efficiency (TE) measures}

Table 3 presents average TE scores for the various groupings. The data at the top of the table shows an average TE at the vineyard level equal to $77.2 \%$, with a range from 41.4 to $92 \%$ and a standard deviation of 10.59 . At the block level, the average is $77.8 \%$, with a low of $23.4 \%$ and a high of $95.0 \%$ and a standard deviation of 13.85. As expected, the TE scores show a wider dispersion at the block level than at the vineyard level (Table 3). Therefore, these results reveal considerable variability in managerial performance and also show that the least efficient operations and blocks have a major gap to close to achieve average performance levels.

The age of the plantation influences the TE scores. When the vineyard has been planted for more than five years, a higher TE score (77.9\%) is found, compared with a younger plantation (75.9\%). However, this difference is not statistically significant (at the $5 \%$ level). It is important to note that the data includes vineyards that are three years old and older. Table 3 also includes a TE comparison by type of wine, and the results indicate that the average TEs for white and red wines are very similar, $77.3 \%$ and $78.0 \%$, respectively (at the $5 \%$ level).

The TE scores are significantly different $(10 \%$ level) for varietal quality grapes $(79.2 \%)$ com- 
Table 3. Technical efficiency measures by categories.

\begin{tabular}{|c|c|c|c|}
\hline Variable & Average, $\%$ & Min., \% & Max., \% \\
\hline \multicolumn{4}{|l|}{ Average: } \\
\hline - By farm & 77.2 & 41.4 & 92.0 \\
\hline - By block & 77.8 & 23.4 & 95.0 \\
\hline \multicolumn{4}{|l|}{ Age of plantation: } \\
\hline - Less or equal to 5 years & 75.9 & 23.4 & 94.4 \\
\hline - Greater than 5 years & 77.9 & 24.5 & 95.0 \\
\hline \multicolumn{4}{|l|}{ Type of wine: } \\
\hline - White & 77.3 & 23.4 & 94.6 \\
\hline - Red & 78.0 & 24.5 & 95.0 \\
\hline \multicolumn{4}{|l|}{ Grape quality: } \\
\hline - Varietal ${ }^{1}$ & 79.2 & 39.7 & 94.6 \\
\hline - Premium & 76.3 & 23.4 & 95.0 \\
\hline \multicolumn{4}{|l|}{ Conduction frame: } \\
\hline - Doble frame & 74.8 & 23.4 & 94.6 \\
\hline - Single frame & 78.2 & 35.6 & 95.0 \\
\hline - Trellis & 76.4 & 43.3 & 92.7 \\
\hline - Others & 79.7 & 54.4 & 92.4 \\
\hline \multicolumn{4}{|l|}{ Farm location - valley: } \\
\hline - Limarí and San Antonio & 69.9 & 23.4 & 91.9 \\
\hline - Aconcagua and Cachapoal & 77.6 & 38.5 & 95.0 \\
\hline - Colchagua and Rapel & 78.5 & 38.2 & 93.7 \\
\hline - Casablanca & 79.1 & 62.8 & 94.4 \\
\hline - Curicó & 79.6 & 58.1 & 92.2 \\
\hline - Maipo & 80.9 & 67.0 & 94.6 \\
\hline - Maule & 75.3 & 35.6 & 93.4 \\
\hline
\end{tabular}

${ }^{1}$ Statistically different when compared within each group of variables, $10 \%$ level of significance.

pared to premium quality (76.3\%). Again, this result is likely due to the additional labor needs, a slower harvest rate and the smaller amount of fruit harvested for premium quality grapes, factors that appear to reduce the TE compared with the varietal quality (Table 3). A desirable approach to account for quality-quantity tradeoffs across the different grades of grapes would be to define the dependent variable in terms of the total value of the product. Unfortunately, the data set used in this study does not include output prices, and thus it is not possible to define the dependent variable in value terms.

The results for training systems exhibit no clear pattern. The most frequently used is the simple cordon training system. and this system has one of the highest TE figures (78.2\%) compared with the double cordon training system (74.8\%), which is the second most common system used in the vineyards in our sample. The pergola training system has an intermediate TE value, and the other training systems have a higher value, but both are used in a small number of cases. These results indicate that farmers do tend to use most frequently the frame that gives the highest level of TE (Table 3), although these differences are not statistically significant. In addition, there is no clear TE pattern across farm location. The highest average TE measure is for farms in the Maipo valley (80.9\%), and the lowest TE measure is for those in the Limarí and San Antonio valleys (69.9\%) (Table 3). Again, mean TE scores are not statistically different across the different valleys. 
Finally, Figures 1 and 2 show the distribution of the TE measures. In both cases, at the farm and block levels, the most common TE measure falls between 80 and $90 \%$. As already indicated, the $\mathrm{TE}$ at the block level has a wider distribution compared to the TE measures at the farm level.

In summary, the analysis shows that significant improvements could be achieved by wine grape

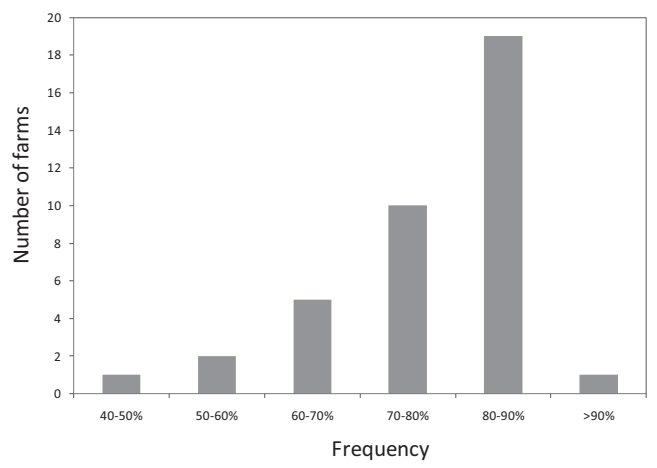

Figure 1. Histogram of technical efficiency measures by farm. growers in Chile. The specific improvements needed could not be examined further with the available data. The results suggest that detailed benchmarking exercises should be undertaken to spell out the management practices that lead to improved performance. This work would need to be done at the block level because the results also suggest considerable TE variability within farms.

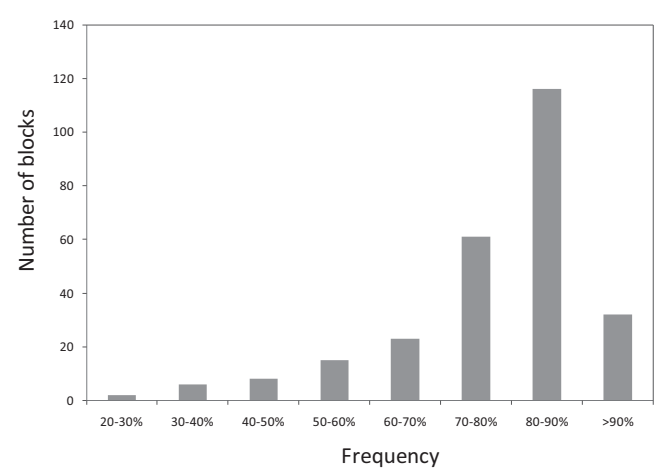

Figure 2. Histogram of technical efficiency measures by block.

\section{Resumen}

V.H. Moreira, J.L. Troncoso y B.E. Bravo-Ureta. 2011. Eficiencia técnica de una muestra de productores chilenos de uva vinífera: Un análisis con fronteras de producción estocástica. Cien. Inv. Agr. 38(3):321-329. Chile se ha transformado en un actor cada vez más importante en el mercado internacional del vino. Junto con la creciente expansión de la producción y exportación de vinos chilenos, otros países del "Nuevo Mundo" han ido aumentando su producción, como es el caso de Argentina, Australia, Nueva Zelanda y Sud África. El aumento de la oferta de vino ha incrementado la competencia entre los países por capturar cuotas de mercado, lo que pone en evidencia la importancia en mejorar la productividad entre productores de vinos y de uva vinífera. El objetivo de este trabajo es estimar y analizar el componente de eficiencia técnica (ET) de la productividad de una muestra de productores de uva chilenos. Los datos provienen de 38 viñedos que entregaron información específica de insumos y productos, para cuarteles individuales, lo que dio un total de 263 observaciones. Se empleó un modelo Cobb-Douglas para estimar la frontera de producción estocástica (FPE) para obtener índices de ET tanto a nivel de cuartel como de viñedo. Los resultados muestran que a nivel de viñedo la ET promedio es $77,2 \%$ en tanto que a nivel de cuartel esta fluctúa entre 23,4 y $95,0 \%$. La cifra del coeficiente de la función es 1,021, lo que indica retornos constantes a escala.

Palabras clave: Chile, fronteras estocásticas de producción, eficiencia técnica, uva vinífera. 


\section{References}

Anderson, K. 2005. The world's wine markets: Globalization at work. Edward Elgar Publishers, London, U. K. 352 pp.

Battese, G.E., and T.J. Coelli. 1992. Frontier production functions, technical efficiency and panel data: With application to paddy farmers in India. J. Prod. Anal. 3:153-169.

Battese, G.E., and T.J. Coelli. 1995. A model for technical inefficiency effects in a stochastic frontier production function for panel data. Empir. Econ. 20:325-332.

Battese, G.E., and G.S. Corra. 1977. Estimation of a production frontier model: With application to the pastoral zone of Eastern Australia. Aust. J. Agric. Econ. 21:169-179.

Bravo-Ureta, B.E., D. Solís, V.H. Moreira, J.F. Maripani, A. Thiam, and T.E. Rivas. 2007. Technical efficiency in farming: A meta-regression analysis. J. Prod. Anal. 27:57-72.

Coelli, T.J. 1996. A guide to frontier version 4.1: A computer program for stochastic frontier production and cost function estimation. CEPA Working Paper 96/7, Department of Econometrics, University of New England, Armidale NSW Australia, Australia.

Coelli, T.J., D.S.P. Rao, and G.E. Battese. 1998. An introduction to efficiency and productivity analysis. Springer, New York. 275 pp.

Conradie, B., G. Cookson, and C. Thirtle. 2006. Efficiency and farm size in Western Cape grape production: Pooling small datasets. South African Journal of Economics 74:334-343.

CORFO - Corporación de Fomento de la Producción. 2004. Estudio de costos comparativos en la industria del vino de la región del Maule. Available online at: http://www.odepa.cl/servlet/sistemas. sice.balanza.ServletBalanzaTrx;jsessionid=D52 E7F080C7312CDE49D76EBF4691790. (Website accessed March, 2004).

Escobar, F. 2007. Competitividad, comportamiento y evolución del vino chileno en los mercados de destino. Thesis Ingeniero Agrónomo. Escuela de Agronomía, Universidad de Talca. Talca, Chile. $63 \mathrm{pp}$.

Foster, W., and A. Valdés. 2001. An overview of wine production and export in Chile and Argentina. Workshop Paper No. 03. Centre for International Economic Studies (CIES). Adelaide University, Australia.

Greene, W.H. 1993. The econometric approach to efficiency analysis. pp. 67-119. In: H. O. Fried, C. A. K. Lovell, and S. S. Schmidt (eds.). The measurement of productive efficiency. Oxford University Press. New York, USA.

Henriques, P.D.d.S., M.L.d.S. Carvalho, and R.M.d.S. Fragoso. 2009. Technical efficiency of Portuguese wine farms. New Medit 1:4-9.

Jondrow, J., C.A.K. Lovell, I.S. Materov, and P. Schmidt. 1982. On the estimation of technical inefficiency in the stochastic frontier production function model. J. Econom. 19:233-238.

ODEPA - Oficina de Estudios y Políticas Agropecuarias, Ministerio de Agricultura. 2010a. Superficie y producción de vides para vinificación, de mesa y pisqueras. Available online at: http:// www.odepa.cl/servlet/articulos.ServletMostrarD etalle;jsessionid=D52E7F080C7312CDE49D76 EBF4691790?idcla=12\&idn=1739. (Website accessed March, 2010).

ODEPA - Oficina de Estudios y Políticas Agropecuarias, Ministerio de Agricultura. 2010b. Servicio de información de la agricultura chilena. Available online at: http://www.odepa.cl/servlet/sistemas.sice.balanza.ServletBalanzaTrx;jsessionid =D52E7F080C7312CDE49D76EBF4691790. (Website accessed March, 2010).

Tecnovid. 2010. Qué es Tecnovid. Available online at: http://www.tecnovid.cl/ques.html. (Website accessed March 2010).

Townsend, R., J. Kirsten, and N. Vink. 1998. Farm size, productivity and returns to scale in agriculture revisited: A case of wine producers in South Africa. Agric. Econ. 19:175-180. 
